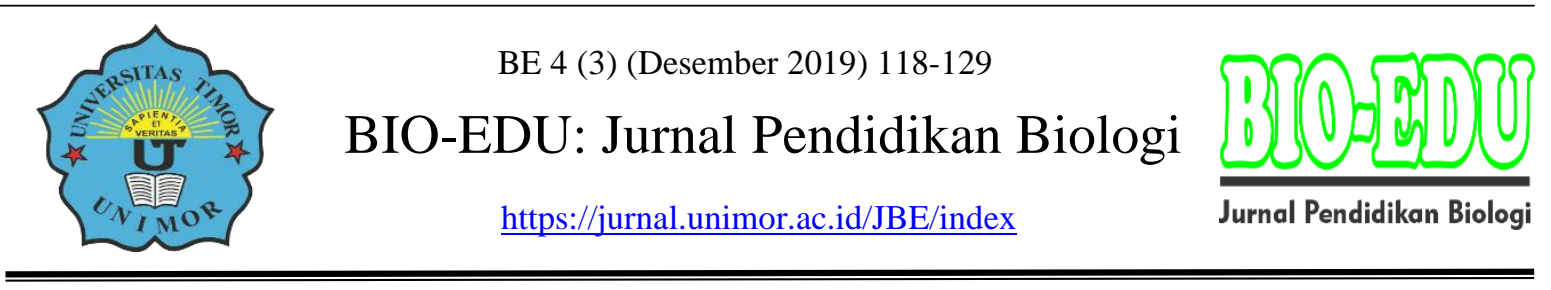

\title{
Hubungan Motivasi Belajar Dengan Prestasi Akademik Siswa Pada Mata Pelajaran Biologi di Kelas X SMA Negeri Insana Tengah Maubesi
}

\author{
Febiana Y. Nahak ${ }^{1}$, E. Kristanti ${ }^{2}$, Finsensius Otepah ${ }^{3}$ \\ ${ }^{1}$ Program Studi Pendidikan Biologi, Universitas Timor \\ ${ }^{2}$ Program Studi Pendidikan Bahasa dan Sastra Indonesia, Universitas Timor \\ ${ }^{3}$ Program Studi Pendidikan Biologi, Universitas Timor \\ Email: riabinsasi@gmail.com
}

DOI: https://doi.org/10.32938/jbe.v4i3.490

\begin{abstract}
Abstrak
Penelitian dengan judul Hubungan Motivasi Belajar dan Prestasi Akademik Siswa Pada Mata Pelajaran Biologi Di Kelas X SMA Negeri Insana Tengah, Maubesi bertujuan untuk mengetahui besarnya motivasi belajar siswa pada mata pelajaran biologi, untuk mengetahui tingkat prestasi akademik siswa dan melihat seberapa besar peran motivasi terhadap prestasi akademik siswa. Teknik analisis data yang digunakan dalam penelitian ini adalah Korelasi Produk Moment. Hasil penelitian menunjukkan bahwa rata-rata motivasi belajar siswa pada mata pelajaran Biologi Kelas X SMAN Insana Tengah Maubesi adalah sebesar 144,82 dengan nilai tertinggi 185 dan nilai terendah yang diperoleh adalah sebesar 97, termasuk kedalam kategori TINGGI, sedangkan ratarata prestasi akademik siswa pada mata pelajaran Biologi kelas X di SMAN Insana Tengah Maubesi sebesar 80,72 dengan nilai tertinggi 92 dan nilai terendahnya adalah 75 , termasuk kedalam kategori sangat tinggi. Hasil analisis Produck Moment menunjukkan tidak terdapat hubungan yang signifikan antara motivasi dengan prestasi akademik siswa pada mata pelajaran Biologi kelas X di SMAN Insana Tengah Maubesi dengan koefisien korelasi sebesar 0,053 termasuk dalam kategori sangat rendah.
\end{abstract}

Kata kunci : Hasil Belajar, Model pembelajaran kooperatif tipe Student Teams Achievement Division

\begin{abstract}
Research with the title Relationship of Student Motivation and Academic Achievement in Biology Subjects in Class X Middle Insana Middle School, Maubesi aims to find out the magnitude of student motivation in biology, to determine the level of student academic achievement and see how much the role of motivation on academic achievement the student. The data analysis technique used in this research is Product Moment Correlation. The results showed that the average student motivation in Biology in Class X Middle Insan Maubesi SMAN was 144.82 with the highest value of 185 and the lowest value obtained was 97, included in the HIGH category, while the average academic achievement of students in Biology class X in Middle Maubesi Middle School of 80.72 with the highest score of 92 and the lowest value of 75 , included in the very high category. The results of the Produck Moment analysis show that there is no significant relationship between motivation and academic achievement of students in Biology class X at SMAN Insana Tengah Maubesi with a correlation coefficient of 0.053 included in the very low category.
\end{abstract}

Keywords: Learning outcomes, type cooperative learning model, student teams achievement division 


\section{PENDAHULUAN}

Salah satu upaya yang menjadikan seseorang berprestasi adalah melakukan kegiatan yang berkelanjutan. Artinya, setelah seseorang menyadari potensi dirinya di suatu bidang maka ia akan terus menerus berusaha untuk mengembangkan menjadi kemampuan utama. Dahlan (2008: 59) menyatakan prestasi adalah hasil dari usaha mengembangkan bakat secara terus menerus. Hasil belajar tersebut merupakan prestasi belajar peserta didik yang diukur dari nilai siswa setelah mengerjakan soal yang diberikan oleh guru pada saat evaluasi dilaksanakan. Keberhasilan pembelajaran siswa dalam belajar dapat di pengaruhi oleh faktor dari dalam individu maupun dari luar individu.

Menurut Ahmadi (2004: 138) prestasi belajar yang dicapai seseorang merupakan hasil interaksi berbagai faktor yang mempengaruhinya baik dari dalam diri (faktor internal) maupun dari luar diri (faktor eksternal) individu. Faktor dari dalam diri meliputi faktor fisik dan psikis, diantaranya adalah minat siswa.

Motivasi belajar mempunyai peranan yang penting untuk belajar, yaitu memberikan gairah atau semangat dalam belajar. Motivasi belajar tidak hanya menjadi pendorong untuk mencapai hasil yang baik tetapi mengandung usaha untuk mencapai tujuan belajar, dimana terdapat pemahaman dan pengembangan dari belajar. Dengan motivasi belajar, setiap peserta didik yang memotivasi dirinya untuk belajar semata-mata bukan hanya untuk mengetahui tetapi lebih kepada untuk memahami hasil pembelajaran tersebut (E. Kristanti 2013).

Motivasi didefenisikan sebagai motif atau hal yang sudah menjadi aktif pada saat tertentu, terutama bila kebutuhan untuk mencapai tujuan terasa sangat mendesak. (Woodworth dan Marquis dalam Abror, 1993). Motivasi adalah proses yang memberi semangat, arah dan kegigihan perilaku yang penuh energi, terarah dan bertahan lama (Santrock, 2005).

Motivasi mempunyai peran penting dalam kegiatan belajar. Motivasi adalah tenaga yang menggerakkan dan mengarahkan aktivitas seseorang apabila pelajaran itu dirasakan sebagai sesuatu yang dibutuhkan diperlukan untuk belajar lebih lanjut dalam kehidupan sehari-hari,akan membangkitkan motivasi untuk mempelajarinya.Menurut slamento (2003:2) "Belajar ialah suatu proses usaha yang dilakukan untuk memperoleh suatu perubahan tingkah laku yang baru secara keseluruhan, sebagai hasil pengelamannya sendiri dalam interaksinya dengan lingkungannya". Jika dihubungkan dengan pembelajaran biologi maka pada hakekatnya merupakan suatu usaha untuk berinteraksi dengan lingkungan, dalam lingkungan ini lingkungan sosial dan alam sekitar. Pengukuran belajar biologi dapat dilihat dari hasil nilai tes ujian (ulangan). Siswa memerlukan motivasi agar mereka bersemangat. Motivasi sendiri bukan merupakan suatu kekuatan yang netral atau kekuatan yang kebal terhadap pengaruh faktor-faktor lain misalnya: pengelaman masa lampau, taraf intelengensi, kemampuan fisik, situasi lingkungan, cita-cita hidup dan sebagainya (Martin H, 1992:9). Berdasarkan pendapat ini dapat diketahui bahwa motivasi yang ada pada diri individu tentunya berbeda-beda, sehingga apabila dihubungkan dengan prestasi belajar, maka kelancaran belajar yang akan dialami siswa pun berbeda-beda.

Motivasi mempunyai kaitan yang erat dengan minat. Siswa yang memiliki minat terhadap suatau bidang studi tertentu tersebut serta mempengaruhi nilai-nilai yang dianggap penting dalam kehidupan. Nilai-nilai yang dianut akan mengubah tingakh laku manusia dan motivasinya, sehingga bahan-bahan pelajaran yang disajikan hendaknya disesuaikan dengan

119 |Y. Nahak/JBE 4(3) (Desember 2019) 118-129 
minat siswa dan tidak bertantangan dengan nilai-nilai yang berlaku. Berdasarkan latar belakang di atas, maka Penulis ingin melakukan penelitian dengan judul "Hubungan Motivasi Belajar Dengan Prestasi Akademik Siswa Pada Mata Pelajaran Biologi Di Kelas X SMA Negeri Insana Tengah Maubesi”.

\section{METODE}

Penelitian dilaksanakan Bulan Mei 2017 di SMA Negeri Insana Tengah Maubesi. Penelitian ini merupakan penelitian korelasi, dimana akan dilaksanakan di SMA N Insana Tengah pada siswa kelas XI IPA. Dari seluruh populasi yakni kelas XI IPA yang dijadikan sampel ad akelas XI IPA 3 dengan jumlah siswa 19 orang. Penarikan sampel ini di peroleh melalui teknik sampel purposive (berdasakan pertimbangan dari peneliti). Untuk memperoleh data motivasi belajar peneliti menggunakan kuisioner sedangkan untuk prestasi belajar siswa, peneliti mengambil langsung data dari guru mata pelajaran yang siswa yang menjadi sampel penelitian. Teknik pengolahan data dalam penenelitian ini menggunkan korelasi produk moment.

\section{HASIL DAN PEMBAHASAN}

\section{Hasil}

Hasil penelitian yang dimaksudkan di atas adalah menyangkut beberapa masalah pokok yang tertuang dalam rumusan masalah yaitu deskripsi tentang motivasi belajar dan prestasi belajar Biologi siswa.

\section{Variabel X (Motivasi Belajar)}

Berdasarkan pada hasil angket yang disampaikan kepada 163 orang responden (sampel penelitian) dengan kuesioner yang terdiri atas 39 butir pertanyaan diperoleh skor tertinggi adalah 185 dari skor maksimal yang bisa dicapai oleh siswa yaitu 1, skor terendah adalah 97 dari nilai terendah yang bisa dicapai yaitu 3, nilai rata-rata (mean) adalah 144,82 dan standar deviasi sebesar 17,163. Untuk lebih ringkasnya, dapat dilihat pada tabel berikut:

Tabel 1. Deskripsi Motivasi Belajar Siswa

\begin{tabular}{|l|l|l|r|r|}
\hline \multicolumn{2}{|l|}{} & Statistic & $\begin{array}{c}\text { Std. } \\
\text { Error }\end{array}$ \\
\hline $\begin{array}{l}\text { Motivasi } \\
\text { Belajar }\end{array}$ & Mean & 144,82 & 1,344 \\
\hline & $\begin{array}{l}\text { 95\% Confidence } \\
\text { Interval for Mean }\end{array}$ & $\begin{array}{l}\text { Lower } \\
\text { Bound }\end{array}$ & 142,17 & \\
\hline & $\begin{array}{l}\text { Upper } \\
\text { Bound }\end{array}$ & 147,48 & \\
\hline & 5\% Trimmed Mean & 145,01 & \\
\hline & Median & 145,00 & \\
\hline & Variance & 294,567 & \\
\hline & Std. Deviation & 17,163 & \\
\hline
\end{tabular}




\begin{tabular}{|l|l|r|r|}
\hline & Minimum & 97 & \\
\hline & Maximum & 185 & \\
\hline & Range & 88 & \\
\hline & Interquartile Range & 27 & \\
\hline & Skewness &,- 171 &, 190 \\
\hline & Kurtosis &,- 479 &, 378 \\
\hline
\end{tabular}

Sumber: Hasil Analisis Statistik

Berdasarkan tabel di atas, dapat diketahui gambaran data secara umum mengenai nilai maksimum, nilai minimum, range, standar deviasi, standar error, mean, median, varian dan sebagainya. Namun demikian secara khusus tabel tersebut belum memberikan jawaban terhadap pertanyaan berapa banyak siswa yang memiliki motivasi tinggi, sedang atau rendah. Dalam artian bahwa data tersebut perlu diurai kembali menjadi bagian yang lebih rinci ke dalam tabel frekuensi dan histogram, sehingga orang lain dapat memahami dengan lebih mudah.

Guna keperluan penyusunan interval dan pembuatan grafik tingkat kecenderungan motivasi belajar siswa dilakukan beberapa langkah yaitu: 1) mengurutkan data dari nilai data tertingi (Xmaks) ke nilai data terrendah (Xmin) atau sebaliknya; kemudian hitung nilai rentangnya $(r)$ dengan rumus $: r=X m a k s-X m i n ; 2)$ menentukan jumlah kelas interval yang akan digunakan pada tabel distribusi frequensi dengan menggunakan rumus Sturgess yaitu $\mathrm{bk}=1+3,3 \log \mathrm{n}$, dimana bk adalah jumlah kelas interval dan $\mathrm{n}$ adaah banyaknya data observasi; 3) menentukan panjang kelas interval dengan rumus $\mathrm{p}=\mathrm{r} / \mathrm{bk}$, dimana $\mathrm{p}$ adalah kelas interval, $\mathrm{r}$ adalah rentang yaitu selisih nilai data terbesar dan nilai data terkecil sedangkan bk adalah banyaknya kelas interval yang diambil dan 5) membuat distribusi frekuensi seperti tabel di bawah ini: (Sundayana, 2014: 38-44)

\section{Tabel 2. Frekuensi skor Motivasi Belajar Siswa kelas $\mathbf{X}$ SMAN Insana Tengah Maubesi}

\begin{tabular}{|c|c|c|}
\hline Nilai & Frekuensi & Frel \% \\
\hline $97-108$ & 3 & 1,8 \\
$109-120$ & 10 & 6,1 \\
$121-132$ & 33 & 20,3 \\
$133-144$ & 32 & 19,6 \\
$145-156$ & 36 & 23,3 \\
$157-168$ & 35 & 21,5 \\
$169-180$ & 11 & 6,8 \\
$181-192$ & 1 & 0,6 \\
Jumlah & $\mathbf{1 6 3}$ & $\mathbf{1 0 0 , 0}$ \\
\hline
\end{tabular}

Dengan melihat tabel tersebut dapat diketahui skor motivasi siswa terbanyak pada interval 145 - 156 yaitu sebanyak 36 orang atau 23,3\%, sebaliknya sebaran skor motivasi belajar siswa yang paling sedikit terdapat pada interval 97 - 108 sebanyak 3 orang $(1,8 \%)$ dan interval $181-192$ sebanyak 1 orang $(0,6 \%)$. Apabila frekuensi skor perolehan motivasi belajar tersebut dimasukkan ke dalam grafik (histogram), maka akan tampak gambar sebagai berikut: 


\section{Gambar 1. Grafik Tingkat Kecenderungan Motivasi Belajar Siswa}

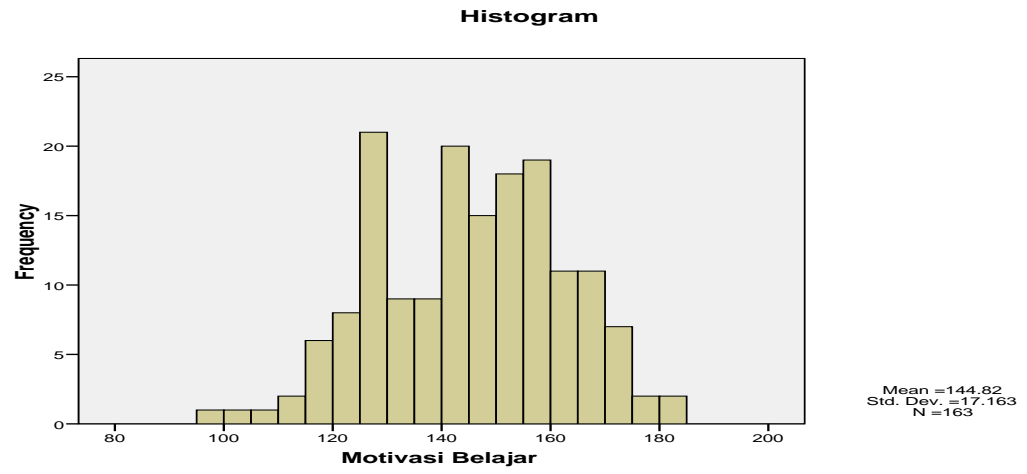

Untuk mengetahui tingkat kecenderungan skor motivasi belajar siswa kelasX SMAN Insana Tengah Maubesi dapat dilakukan dengan mencari mean ideal dan standar deviasi ideal sebagai berikut: 1) skor maksimal ideal 195 dan minimal 39, diperoleh mean ideal (Mi) = 1/2 (Skor maksimal + skor minimal) sehingga diperoleh $\mathrm{Mi}=1 / 2(195+39)=117$, sedangkan SDi $=1 / 6$ (skor maksimal - skor minimal $=1 / 6(195-39)=26$. Nilai SDi dan Mi kemudian dikonversikan ke dalam tabel kecenderungan dengan 5 (lima) kategori sebagaimana berikut:

1. Sangat Tinggi $: \mathrm{Mi}+1,5 \mathrm{SDi}-\mathrm{Mi}+3,0 \mathrm{SDi}$

2. Tinggi : $\mathrm{Mi}+0,5 \mathrm{SDi}-\mathrm{Mi}+1,5 \mathrm{SDi}$

3. Sedang : $\mathrm{Mi}-0,5 \mathrm{SDi}-\mathrm{Mi}+0,5 \mathrm{SDi}$

4. Rendah : $\mathrm{Mi}-1,5 \mathrm{SDi}-\mathrm{Mi}-0,5 \mathrm{SDi}$

5. Sangat Rendah : $\mathrm{Mi}-3,0 \mathrm{SDi}-\mathrm{Mi}-1,5 \mathrm{SDi}$

Tabel 3. Kecenderungan Motivasi Belajar Siswa

\begin{tabular}{|c|c|c|}
\hline No & Interval & Kategori \\
\hline 1 & $156-195$ & Sangat Tinggi \\
2 & $130-156$ & Tinggi \\
3 & $104-130$ & Sedang \\
4 & $78-104$ & Rendah \\
5 & $29-78$ & Sangat Rendah \\
\hline
\end{tabular}

Rata-rata (mean) skor motivasi belajar sebesar 144,8 terletak pada rentangan 130 156 yaitu termasuk ke dalam kategori tinggi.

\section{Variabel Y (Prestasi Belajar Siswa)}

Berdasarkan hasil tes semester akhir pada mata pelajaran Biologi di kelas X SMAN Insana Tengah Maubesi didapat nilai prestasi akademik Biologi diperoleh skor atau nilai tertinggi 92 dan skor atau nilai terendah adalah 75. Adapun distribusi frequensi prestasi akademik mata pelajaran Biologi dapat dilihat pada tabel di bawah ini: 


\section{Tabel 4. Deskripsi Data Prestasi Akademik Siswa}

\begin{tabular}{|c|c|c|}
\hline \multirow[t]{2}{*}{$\mathrm{N}$} & Valid & 163 \\
\hline & Missing & 0 \\
\hline \multicolumn{2}{|c|}{ Mean } & 80,72 \\
\hline \multicolumn{2}{|c|}{ Std. Error of Mean } &, 279 \\
\hline \multicolumn{2}{|c|}{ Median } & 80,00 \\
\hline \multicolumn{2}{|c|}{ Mode } & 78 \\
\hline \multicolumn{2}{|c|}{ Std. Deviation } & 3,562 \\
\hline \multicolumn{2}{|c|}{ Variance } & 12,685 \\
\hline \multicolumn{2}{|c|}{ Skewness } &, 778 \\
\hline \multicolumn{2}{|c|}{ Std. Error of Skewness } & , 190 \\
\hline \multicolumn{2}{|c|}{ Kurtosis } & ,407 \\
\hline \multicolumn{2}{|c|}{ Std. Error of Kurtosis } & ,378 \\
\hline \multicolumn{2}{|c|}{ Range } & 17 \\
\hline \multicolumn{2}{|c|}{ Minimum } & 75 \\
\hline \multicolumn{2}{|c|}{ Maximum } & 92 \\
\hline \multicolumn{2}{|c|}{ Sum } & 13157 \\
\hline
\end{tabular}

Dari tabel di atas, dapat diketahui gambaran data penelitian mengenai prestasi akademik pada mata pelajaran Biologi, di mana mean (rata-rata) skor perolehan siswa adalah 80,72. Varian sama dengan 12,685 dengan standar deviasi sama dengan 3,562. Skor maksimal peroleh siswa adalah 94.00 dan skor minimum sama dengan 75.00. Sama dengan langkah yang dilakukan pada penyusunan interval dan pembuatan grafik motivasi belajar. Penyusunan interval dan pembuatan grafik tingkat kecenderungan prestasi akademik siswa juga dilakukan dengan beberapa langkah yaitu: 1) mengurutkan/merangking prestasi akademik dari yang skor terendah sampai kepada skor tertinggi, 2) mencari range dengan mengurangi skor maksimal dengan skor minimal, 3) mencari banyaknya kelas dengan rumus sturgess yaitu $\mathrm{BK}=1+3,3 \log \mathrm{n}, 4)$ menentukan panjang kelas dengan membagi range dengan banyaknya kelas, dan 5) membuat distribusi frekuensi sebagaimana berikut :

Tabel 4. Frekuensi skor Prestasi Akademik Mata Pelajaran Biologi Siswa kelas X SMAN Insana Tengah Maubesi

\begin{tabular}{|c|c|c|c|}
\hline No. & Interval & Frequensi & Frel (\%) \\
\hline 1 & $75-77$ & 27 & 17 \\
2 & $78-80$ & $\mathbf{6 1}$ & 37 \\
3 & $81-83$ & 42 & 26 \\
4 & $84-86$ & 22 & 14 \\
5 & $87-89$ & 7 & 4 \\
6 & $90-92$ & 4 & 2 \\
& & & $\mathbf{1 0 0}$ \\
\hline
\end{tabular}

Dengan melihat tabel tersebut dapat diketahui skor prestasi belajar siswa terbanyak pada interval 78 - 80 yaitu sebanyak 61 orang atau $37 \%$, sebaliknya sebaran skor prestasi belajar siswa yang paling sedikit terdapat pada interval 90 - 92 sebanyak 4 orang (2\%). 
Apabila frekuensi skor perolehan prestasi belajar tersebut dimasukkan ke dalam grafik (histogram), maka akan tampak grafik sebagaimana berikut:

Gambar 2. Grafik Tingkat Kecenderungan Prestasi Belajar Siswa

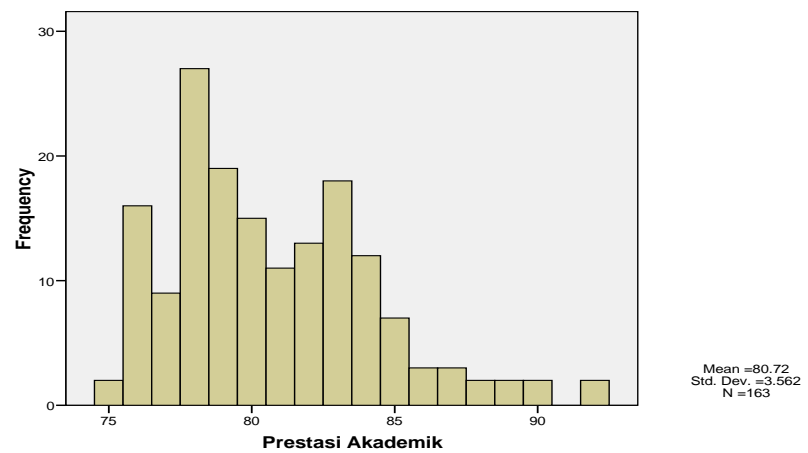

Sedangkan untuk mengetahui tingkat kecenderungan skor prestasi akademik siswa kelas X SMAN Insana Tengah Maubesi, dapat dilakukan dengan mencari mean ideal dan standar deviasi ideal sebagai berikut: 1) skor maksimal ideal 100 dan minimal 0, diperoleh mean ideal $(\mathrm{Mi})=1 / 2($ Skor maksimal + skor minimal $)$ sehingga diperoleh $\mathrm{Mi}=1 / 2(100+0)=50.0$, sedangkan SDi = 1/6 (skor maksimal - skor minimal $=1 / 6(100-0)=16,67$. Nilai SDi dan Mi kemudian dikonversikan ke dalam tabel kecenderungan dengan 5 (lima) kategori sebagaimana berikut:

1. Sangat Tinggi $: \mathrm{Mi}+1,5 \mathrm{SDi}-\mathrm{Mi}+3,0 \mathrm{SDi}$

2. Tinggi $: \mathrm{Mi}+0,5 \mathrm{SDi}-\mathrm{Mi}+1,5 \mathrm{SDi}$

3. Sedang : $\mathrm{Mi}-0,5 \mathrm{SDi}-\mathrm{Mi}+0,5 \mathrm{SDi}$

4. Rendah $\quad: \mathrm{Mi}-1,5 \mathrm{SDi}-\mathrm{Mi}-0,5 \mathrm{SDi}$

5. Sangat Rendah $\quad: \mathrm{Mi}-3,0 \mathrm{SDi}-\mathrm{Mi}-1,5 \mathrm{SDi}$

Tabel 6. PA

\begin{tabular}{|c|c|c|}
\hline NO & Interval & Kategori \\
\hline 1 & $75,5-100$ & Sangat Tinggi \\
2 & $58,5-75,5$ & Tinggi \\
3 & $41,5-58,5$ & Sedang \\
4 & $24,5-41,5$ & Rendah \\
5 & $0,00-24,5$ & Sangat Rendah \\
\hline
\end{tabular}

Rata-rata (mean) skor prestasi akademik pelajaran Biologi siswa kelasX SMAN Insana Tengah Maubesi sebesar 80,72 terletak pada rentangan 75,5 - 100 yaitu termasuk ke dalam kategori sangat tinggi

Uji Persyaratan Analisis

Sebagaimana telah diuraikan sebelumnya, bahwa penelitian ini menggunakan pendekatan kuantitatif dengan tujuan untuk menguji hipotesis statistik tentang ada tidaknya hubungan dan seberapa besar pengaruh motivasi terhadap prestasi belajar. Agar dapat melakukan uji statistic terhadap data penelitian, maka sebelumnya harus dilakukan uji 
persyaratan analisis guna memastikan apakah data penelitian dapat dianalisis dengan menggunakan statistic ataukah tidak.

\section{Uji Normalitas}

Normalitas sebaran data dalam penelitian ini dianalisis dengan menggunakan teknik Kolmogorof-Smirnov. Perhitungannya menggunakan bantuan program SPSS 15 for Windows. Ringkasan hasil uji normalitas data dapat dilihat pada tabel berikut.

Tabel 7. Uji Normalitas Motivasi Belajar

\begin{tabular}{|l|r|c|c|c|c|c|}
\hline \multirow{2}{*}{} & \multicolumn{3}{|c|}{$\begin{array}{c}\text { Kolmogorov- } \\
\text { Smirnov(a) }\end{array}$} & \multicolumn{3}{c|}{ Shapiro-Wilk } \\
\cline { 2 - 7 } & Statistic & Df & Sig. & $\begin{array}{c}\text { Statis } \\
\text { tic }\end{array}$ & Df & Sig. \\
\hline Motivasi Belajar &, 067 & 163 &, 070 &, 989 & 163 &, 234 \\
\hline
\end{tabular}

a Lilliefors Significance Correction

Dari tabel di atas, nilai signifikansi yang diperoleh dengan teknik KolmogorofSmirnov adalah 0,070. Sesuai dengan aturan pengambilan keputusan yang telah ditetapkan sebelumnya yaitu : jika signifikansi yang diperoleh $>\alpha$, maka sampel berasal dari populasi yang berdistribusi normal.

Jika signifikansi yang diperoleh $<\alpha$, maka sampel bukan berasal dari populasi yang berdistribusi normal. Dari hasil analisis ternyata nilai signifikansi yang diperileh $>\alpha$ atau $0,070>0,05$ sehingga dapat disimpulkan bahwa sebaran data motivasi belajar berdistribusi Normal.

Sedangkan sebaran data prestasi belajar siswa dengan menggunakan teknik yang sama dapat dilihat pada tabel berikut ini:

Tabel 8. Uji Normalitas Prestasi Akademik

\begin{tabular}{|c|c|c|c|c|c|c|}
\hline & \multicolumn{3}{|c|}{$\begin{array}{l}\text { Kolmogorov- } \\
\text { Smirnov(a) }\end{array}$} & \multicolumn{3}{|c|}{ Shapiro-Wilk } \\
\hline & $\begin{array}{l}\text { Stati } \\
\text { stic }\end{array}$ & Df & Sig. & $\begin{array}{l}\text { Stati } \\
\text { stic }\end{array}$ & Df & Sig. \\
\hline Prestasi Akademik &, 133 & 163 &, 000 & ,943 & 163 &, 000 \\
\hline
\end{tabular}

a Lilliefors Significance Correction

Dari tabel di atas, nilai signifikansi yang diperoleh dengan teknik KolmogorofSmirnov adalah 0,000. Sesuai dengan aturan pengambilan keputusan yang telah ditetapkan sebelumnya yaitu : jika signifikansi yang diperoleh $>\alpha$, maka sampel berasal dari populasi yang berdistribusi normal.

Jika signifikansi yang diperoleh $<\alpha$, maka sampel bukan berasal dari populasi yang berdistribusi normal. Dari hasil analisis ternyata nilai signifikansi yang diperileh $>\alpha$ atau $0,000<0,05$ sehingga dapat disimpulkan bahwa sebaran data prestasi akademik berdistribusi tidak Normal.

\section{Uji Linieritas Data}

Untuk mengetahui hubungan variable motivasi belajar dan prestasi belajar siswa pada mata pelajaran Biologi memiliki hubungan yang linier, dalam penelitian ini digunakan 
bantuan program SPSS 15 for windows. Ringkasan hasil uji linieritas data diberikan pada tabel berikut:

Tabel 9. ANOVA

\begin{tabular}{|l|l|l|r|r|r|r|r|}
\hline & \multicolumn{2}{|l|}{} & $\begin{array}{c}\text { Sum of } \\
\text { Squares }\end{array}$ & df & $\begin{array}{c}\text { Mean } \\
\text { Square }\end{array}$ & F & Sig. \\
\hline $\begin{array}{l}\text { Prestasi } \\
\begin{array}{l}\text { Akademik } \\
* \text { Motivasi } \\
\text { Belajar }\end{array}\end{array}$ & $\begin{array}{l}\text { Between } \\
\text { Groups }\end{array}$ & (Combined) & 922,440 & 61 & 15,122 & 1,349 &, 091 \\
\hline & & Linearity & 5,772 & 1 & 5,772 &, 515 &, 475 \\
\hline & $\begin{array}{l}\text { Deviation } \\
\text { from } \\
\text { Linearity }\end{array}$ & 916,668 & 60 & 15,278 & 1,362 &, 085 \\
\hline & \multicolumn{2}{l|}{ Within Groups } & 1132,579 & 101 & 11,214 & & \\
\hline
\end{tabular}

Berdasarkan tabel Anova di atas, dapat dilihat bahwa nilai F pada Deviation from Linierity adalah 1,362 dengan signifikansi 0,085 > 0,05, yang berarti model regresi linear.

\section{Uji Hipotesis}

Analisis data yang digunakan dalam penelitian ini adalah analisa regresisederhana untuk melihat sejauh mana peran motivasi belajar terhadap prestasi akademik siswa kelas X SMAN Insana Tengah Maubesi. Berdasarkanan datayang telah dikumpulkan dengan bantuan regression analysis program SPSS 15.0for windows, diperoleh hasil sebagai berikut:

Tabel 10. Uji Hipotesis

\begin{tabular}{|c|c|c|c|c|c|}
\hline Variabel & B & Beta & T & Signifikansi & Keterangan \\
\hline Konstanta & 79,125 & & $\begin{array}{c}33,2 \\
23\end{array}$ & 0,000 & Signifikan \\
\hline $\begin{array}{c}\text { Motivasi } \\
\text { Belajar (X) }\end{array}$ & 0,011 & $\begin{array}{c}0,05 \\
3\end{array}$ & $\begin{array}{c}0,67 \\
3\end{array}$ & 0,502 & $\begin{array}{c}\text { Tidak } \\
\text { signifikan }\end{array}$ \\
\hline $\begin{array}{c}\text { F hitung } \\
\text { Signifikansi } \\
\text { R }\end{array}$ & 0,453 & & & & \\
$\mathrm{R}^{2}$ & 0,502 & & & & \\
\hline
\end{tabular}

Berdasarkan angka-angka yang disajikan tabel di atas maka dapat dibuat persamaan regresi sebagai berikut :

$$
\begin{aligned}
& Y=a+b X \\
& Y=79,125+0,011 X
\end{aligned}
$$


Koefisien regresi motivasi belajar menunjukkan sebesar 0,011. Angka ini mengandung arti bahwa perubahan rata-rata variabel Y untuk setiap perubahan variabel $\mathrm{X}$ sebesar 1 satuan. Konstanta sebesar 79,125 menyatakan bahwa jika tidak ada nilai motivasi belajar maka nilai partisipasi sebesar 79,125. Sedangkan koefisien regresi X sebesar 0,011 yang menyatakan bahwa setiap penambahan 1 nilai motivasi belajar, maka nilai partisipasi bertambah sebesar 0,011. Berdasarkan tabel hasil analisis regresi, kemudian dilakukan pengujian hipotesis melalui uji $F$ dan uji t. Melalui uji t dan uji $F$ tersebut peneliti juga dapat mengetahui besaran pengaruh dari tiap-tiap variabel bebas terhadap variabel tergantung. Hipotesis penelitian ini adalah: "Ada Hubungan Motivasi Belajar Dan Prestasi Akademik Siswa Pada Mata Pelajaran Biologi SMA N Insana Tengah Maubesi”.

Berdasarkan tabel di atas diketahui nilai Thitung sebesar 0,673. Karena nilai T hitung sudah ditemukan, maka langkah selanjutnya kita akan mencari nilai $\mathrm{t}$ tabel. Adapun rumus nilai $\mathrm{t}$ tabel adalah :

Nilai a/2 $=0,05 / 2=0,025$

Derajat kebebasan $(\mathrm{df})=\mathrm{n}-2=163-2=161$

Nilai 0,$025 ; 161$ kemudian kita lihat pada distribusi nilai t tanel, maka didapat nilai $\mathrm{t}$ tabel sebesar : 1,979. Karena nilai t hitung sebesar 0,673 lebih kecil < dari 1,979, sehingga dapat disimpulkan bahwa Ho diterima dan Ha ditolak, yang berarti tidak ada hubungn motivasi belajar dan prestasi akademik

\section{Interpretasi Koefisien Regresi}

$\mathrm{R}$ Square pada tabel di atas menunjukkan nilai koefisien determinasi korelasi motivasi dan prestasi belajar sebesar 0,053 atau sebesar 5,3\%, yang berarti bahwa prestasi akademik Biologi siswa dapat diprediksi sebesar 5,3\% oleh variabel motivasi belajar, sisanya sebesar 94,7\% merupakan kontribusi faktor lain yang tidak diteliti.

\section{Pembahasan}

Berdasarkan analisis hasil penelitian yang telah dilakukan, selanjutnya akan dilakukan pembahasan hasil dari analisis atas peran motivasi belajar terhadap prestasi akademik siswa pada mata pelajaran Biologi.

Dari hasil uji hipotesis, tidak terdapat hubungan yang signifikan antara motivasi belajar dengan prestasi akademik siswa pada mata pelajaran Biologi kelas X di SMA N Insana Tengah Maubesi dengan koefisien korelasi sebesar 0,053, termasuk dalam kategori sangat rendah. Namun demikian ditemukan bahwa motivasi belajar siswa kelas X SMA N Insana Tengah Maubesi cukup tinggi dengan rata-rata sebesar 144,82. Sedangkan prestasi akademik siswa pada mata pelajaran Biologi kelas X di SMA N Insana Tengah Maubesi pun tergolong dalam kategori sangat tinggi dengan nilai rata-rata sebesar 80,72.

Melihat motivasi belajar siswa kelas X SMA N Insana Tengah Maubesi yang cenderung tinggi dan prestasi akademik yang termasuk kategori sangat tinggi menunjukkan bahwa peran motivasi cukup besar terhadap prestasi akademik siswa. Dari hasil penelitian yang tidak menunjukkan hubungan antara motivasi belajar dan prestasi akademik, dapat diasumsikan bahwa prestasi akademik siswa sangat dipengaruhi oleh banyak faktor selain faktor motivasi belajar, misalnya faktor sosial ekonomi orang tua, dukungan sosial, tingkat inteligensi atau kecerdasan, bakat, minat, dan lain sebagainya. 


\section{KESIMPULAN}

Berdasarkan data hasil penelitian dapat disimpulkan bahwa:

1. Rata-rata motivasi belajar siswa pada mata pelajaran Biologi Kelas X SMA N Insana Tengah Maubesi adalah sebesar 144,82 dengan nilai tertinggi 185 dan nilai terendah yang diperoleh adalah sebesar 97, termasuk kedalam kategori tinggi.

2. Rata-rata prestasi akademik siswa pada mata pelajaran Biologi kelas X di SMA N Insana Tengah Maubesi sebesar 80,72 dengan nilai tertinggi 92 dan nilai terendahnya adalah 75, termasuk kedalam kategori sangat tinggi.

3. Tidak terdapat hubungan yang signifikan antara motivasi dengan prestasi akademik siswa pada mata pelajaran Biologi kelas X di SMA N Insana Tengah Maubesi dengan koefisien korelasi sebesar 0,053, termasuk dalam kategori sangat rendah.

\section{DAFTAR RUJUKAN}

Ahmadi, 2004. Psikologi Sosial. Jakarta: Rineka Cipta.

Arikunto, Prof. Dr. Suharsimi. 2006. Prosedur Penelitian Suatu Pendekatan Praktek (Revisi VI) Metode Penelitian Kuantitatif. Jakarta: Kencana Prenada.

Azwar, Saifuddin. 2007. Metode penelitian. Jogyakarta. Pustaka Pelajar.

Benyamin S Bloom Nurman. 2006. Evaluasi dan Penelitian Pendidikan Biologi. Bandung Angkasa.

Dahlan, Sopiyudin. 2008. Pengaruh Motivasi Belajar. Jakarta: Salemba Medika.

Dalyono, 2001. Psikologi Pendidikan. PT. Rineka Cipta. Jakarta.

Dimyati. 1994. Statistik Penelitian Pendidikan. Bandung. Penerbit: Alfabeta.

E. Kristanti. 2003. Kontribusi Iklim kelas dan Self-Eficacy Terhadap Motivasi Belajar Peserta Didik. Jurnal Matematika Dan Ilmu Pengetahuan Alam. Media Sains. Edisi Khusus, Mei 2013.

Hadi, Sutrisno. 2016. Statistik. Yogyakarta: Pustaka Pelajar

Hamalik, O. 19992. Psikologi Belajar dan Mengajar. Bandung: Sinar Baru Bandung.

Martin, H. 1992. Motivasi Daya Penggerak Tingkah Laku. Jakarta: PT Rineka Cipta.

Mudjiono. 2002. Belajar dan Pembelajaran. Jakarta: Rineka Cipta.

Nurman, 2006. Interaksi dan Prestasi Belajar. Bandung: PT Rineka Cipta

Nasution. 1995. Dasar-Dasar Pendidikan. Jakarta: Rineka Cipta.

Nashar.2004. Peranan Motivasi Dan Kemampuan Awal Dalam Kegiatan Pembelajaran. Jakarta: Delia Press

Natawijaya, 1979. Landasan Psikologi Proses Pendidikan. Bandung: PT Remaja Rosdakarya.

Purwanto, N.2003. Psikologi Pendidikan. Bandung: PT Remaja Rosdakarya.

Riduwan, Sunarto. 2015. Pengantar Statistik. Bandung. Alfabeta.

128 |Y. Nahak/JBE 4(3) (Desember 2019) 118-129 
Sundayana, Rostina. 2014. Statistik Penelitian Pendidikan. Alfabeta.

Santrock. 2007. Faktor-Faktor Yang Mempengaruhi Motivasi.Jakarta: Bina Aksara.

Sardiman A. M. 2005. Interaksi dan Motivasi Belajar Mengajar, Jakarta: PT Raja Grafindo Persada.

Slameto. 2003. Belajar dan Faktor-Faktor yang Mempengaruhi. Jakarta: Bina Aksara.

Sondang, P.2004. Teori Motivasi dan Aplikasinya. Jakarta: PT Rineka Cipta.

Sugyono. 2014. Metode Penelitian Pendidikan. Bandung: alfabeta.

Sukmadinata. N. 2003. Landasan Psikologi Proses Pendidikan. Bandung: PT Remaja Rosdakarya.

Sumadi, S. 2005. Psikologi Pendidikan. Jakarta: PT Raja Grafindo Persada.

Syah, M. 2005. Psikologi Pendidikan dengan Pendekatan Baru. Bandung: Remaja Rosdakarya.

Sudjana, N. 1994 Penelitian Hasil Proses Belajar Mengajar. Bandung Remaja Rosdakarya..

Soeitoe. 1987. Dikdatik Asas-Asas Mengajar. Jakarta: PT Bina Aksara.

Winkel. 1991. Faktor-Faktor yang Mempengaruhi Prestasi Belajar. Bandung Alfabeta.

Wlodkowsky, S. 2007. Psikologi Pengajaran.Jakarta: Gramedia.

Yusuf, 1992. Pengantar Bimbingan Konseling. Jakarta Gramedia Pustaka.

Zaenal, A. 1990. Evaluasi Instruksi Prinsip-Teknik-Prosedur. Bandung: Remaja.

Z. F. Kawareh.1995. Pengembangan Minat Belajar. Jakarta: Bina Keluarga. 